\title{
Impacts of LED spectral quality on leafy vegetables: Productivity closely linked to photosynthetic performance or associated with leaf traits?
}

\author{
Jie He ${ }^{1 *}$, Lin Qin $^{1}$, Wah Soon Chow ${ }^{2}$ \\ (1. National Institute of Education, Nanyang Technological University, 1 Nanyang Walk, Singapore 637616; \\ 2. Division of Plant Sciences, Research School of Biology, The Australian National University, 46 Sullivans Creek Road, \\ ACTON, ACT 2601, Australia)
}

\begin{abstract}
The success of growing vegetables indoors requires the most appropriate selection of lighting spectrum. This mini review discusses the impacts of LED spectral quality on different leafy vegetables with a focus on the studies of Chinese broccoli (Brassica alboglabra), ice plants (Mesembryanthem crystallinum) and lettuce (Lactuca sativa L. cv. Canasta). For each species, plants exposed to different spectral LED lights were all under the same light intensity and same photoperiod. Chinese broccoli grown under red(R):blue(B)-LED ratio of 84:16 (16B) had the highest light-saturated photosynthetic $\mathrm{CO}_{2}$ assimilation rate $\left(A_{s a t}\right)$ and stomatal conductance $\left(g_{s}\right.$ sat $)$ compared to plants grown under other R:B-LED ratios. It was also shown that $16 \mathrm{~B}$ is the most appropriate selection for Chinese broccoli to achieve the highest shoot productivity with a rapid leaf number and leaf area development. The highest concentrations of photosynthetic pigments, soluble and Rubisco protein on a leaf area basis were also observed in 16B plants. The results conclusively affirmed that the highest productivity of Chinese broccoli grown under 16B is closely linked to the highest photosynthetic performance on a leaf area basis. For ice plants grown under R:B-LED ratios of 90:10 (10B), they had the highest shoot biomass with a faster leaf development compared to plants grown under other RB-LED combinations. However, there were no differences in $A_{\text {sat }}, g_{s}$ sat, photosynthetic pigments, soluble and Rubisco proteins on a leaf area basis. In the case of lettuce plants, it was a surprise to observe that plants grown under 0B and 20G (20\% green (G)-LED and 80\% R-LED) had the highest shoot biomass, and largest total leaf area and light interception area but the lowest net maximal photosynthetic rate on a leaf area basis, compared to other plants. The combined RB-LED enhanced other photosynthetic parameters while $0 \mathrm{~B}$ and $20 \mathrm{G}$ conditions had inhibitory effects on maximum quantum efficiency of PS II with lower photosynthetic pigments, total soluble protein and Rubisco protein. These results suggest that impacts of LED light quality on productivity of lettuce ( $L$. sativa L. cv. Canasta) are closely linked to leaf traits not associated with photosynthetic performance on a leaf area basis.
\end{abstract}

Keywords: leafy vegetable, leaf traits, LED spectral quality, photosynthetic performance, productivity DOI: $10.25165 / \mathrm{j}$.jjabe.20191206.5178

Citation: He J, Qin L, Chow W S. Impacts of LED spectral quality on leafy vegetables: Productivity closely linked to photosynthetic performance or associated with leaf traits? Int J Agric \& Biol Eng, 2019; 12(6): 16-25.

\section{Introduction}

The economic success of the vertical farming system depends on providing sufficient uniform lighting to the plants, to allow fast growth but with minimal energy utilization ${ }^{[1-4]}$. Light-emitting diodes (LED) lighting used in both the greenhouse and indoor crop production has received a greater deal of international effort in the past two decades ${ }^{[5,6]}$. LED allows the manipulation of the light spectra, thus enabling the most appropriate selection of lighting environment for the individual crop to enhance growth and productivity in a cost-effective manner ${ }^{[6-8]}$.

The quality of light is especially important for plant growth when artificial light is used for indoor farming ${ }^{[8-11]}$. Compared to

\section{Received date: $2019-08-22 \quad$ Accepted date: 2019-10-15}

Biographies: Lin, Qin, PhD, Research Fellow, research interests: LED impacts on photosynthesis and vegetable production, Email: lin.qin@nie.edu.sg; Wah Soon Chow, PhD, Professor, research interests: photoinactivation of photosystem II, acclimation of photosynthesis to the light environment, Email: Fred.Chow@anu.edu.au.

*Corresponding author: Jie $\mathrm{He}, \mathrm{PhD}$, Associate Professor, research interests: plant stress physiology, LED impacts on photosynthesis and vegetable production, Address: National Institute of Education, Nanyang Technological University, 1 Nanyang Walk, 637616, Singapore. Email: jie.he@nie.edu.sg.
R-LED alone, combined RB-LED promotes growth in pepper ${ }^{[12,13]}$, wheat $^{[14]}$, lettuce ${ }^{[15,16]}$, spinach and radish ${ }^{[15]}$, strawberry plantlet ${ }^{[17]}$, rapeseed rosette leaves ${ }^{[18]}$, cucumber seedling ${ }^{[19]}$, common ice plant $^{[20]}$, Chinese broccoli ${ }^{[21,22]}$ and rapeseed (Brassica napus L.) plantlets in vitro ${ }^{[23]}$. Although green wavelength (500 to $600 \mathrm{~nm}$ ) is photosynthetically inefficient, it has been shown to have specific effect on various plant processes ${ }^{[24-28]}$. Enhanced lettuce growth when green light was supplemented to combined red and blue light was attributed to the better penetration of green light into the deeper canopy ${ }^{[24,27-29]}$. However, other researchers reported that monochromatic green light inhibited plant growth, especially at the seedling stage of lettuce ${ }^{[30]}$ and tomato ${ }^{[31]}$.

The blue and red light absorption by plants is as high as $90 \%{ }^{[27]}$, implying that plant development and photosynthetic process are strongly influenced by the combinations of blue and red lights ${ }^{[9,16,32-33]}$. For instance, red light supplemented with blue light could prevent elongation growth and leaf expansion ${ }^{[16,34,35]}$. Blue light affects the photosynthetic process directly by regulating stomatal movement ${ }^{[19,36]}$, chloroplast development ${ }^{[13,37]}$ and chlorophyll (Chl) synthesis ${ }^{[20,38]}$. For example, Schuerger et al. ${ }^{[13]}$ examined the changes in leaf anatomy of pepper under different colour combinations of light. Their results indicated that leaf thickness and number of chloroplasts per cell depended much more 
on the level of blue light than other wavelengths. Blue light also increases photosynthetic light use efficiency through the regulation of PS II efficiency (ФPSII) and electron transport rate $(\mathrm{ETR})^{[20,33,36,39]}$. The expression of PSII-core monomer and PSII-core dimer ${ }^{[40]}$ and $r b c S, r b c L, p s b A, p s b B$ genes are also enhanced by blue light $)^{[31]}$. Some researchers attributed the blue light effects on photosynthesis to a higher nitrogen and Rubisco content $^{[20,40]}$ and Rubisco activity ${ }^{[41]}$. Green light also affects various plant growth developmental and physiological processes such as stomata opening and photosynthesis ${ }^{[24,27,42]}$. For example, green light decreases stomatal conductance in lettuce ${ }^{[24]}$, but increases plant biomass and $\mathrm{Chl}$ content in lettuce seedlings when combined with blue and red light ${ }^{[42]}$. However a high percentage of green light such as $>50 \%$ reduces plant growth $^{[9]}$. Klein ${ }^{[43]}$ reviewed the impacts of green light on plants, and concluded that green light represses plant growth and development.

In Singapore, due to limited land, local farming currently accounts for only $10 \%$ of the leafy vegetables consumed in 2019 . It has been projected that over the next ten years, the local supply of leafy vegetables must increase from $10 \%$ to $30 \%$ by developing high-tech urban farming. LED-integrated vertical farming systems have been developed by our research team for both indoors and greenhouse for different leafy vegetable production ${ }^{[1,2]}$. We have designed and optimized LED lightings for the cultivation of popular and high-valued leafy vegetables and herbs ${ }^{[1,2,16,20-22,44-47]}$. They are Chinese broccoli (B. alboglabra), Na Bai (B. chinensis L.), wild rocket (Eruca sativa), mizuna (B. juncea var. japonica), red and green leaves lettuce ( $L$. sativa), ice plants (M. crystallinum), red- and green-leaved Chinese Basil (Perilla frutescens), kale ( $B$. oleracea, cvs. Curly kale; Kale Toscano and Borecole red); sweet basil (Ocimum basilicum), red and green Chinese Basil (Perilla frutescens). Generally (but not always) combined RB-LED is more effective than only R- or B-LED lighting in enhancing photosynthesis and thus productivity ${ }^{[20-22]}$. The optimal combinations of LED lightings are species-dependent. Different vegetable crops also have different requirements in durations ${ }^{[46]}$ and light intensities ${ }^{[47]}$. Questions about what combinations of LED lighting should be selected for maximal productivity, are still open. The correlations between productivity and photosynthetic performance or morphological changes such as leaf traits are limited. This mini review discusses the impacts of LED quality on different leafy vegetables with a focus on our studies of Chinese broccoli $(B$. alboglabra), ice plants (M. crystallinum) and lettuce (L. sativa $\mathrm{L}$. cv. Canasta).

\section{Productivity is closely linked to both the photosynthetic performance and leaf development of Chinese broccoli (B. alboglabra) under the optimal combination of RB-LED}

In addition to red light, many studies have manipulated the proportion of blue light necessary for normal plant growth $^{[13,15,16,39,48]}$. Supplementing appropriate amount of blue light to red light results in dramatic effects on the morphology and anatomy structure ${ }^{[13,18,23,48-50]}$, chloroplast structure ${ }^{[31,48,51,52]}$ and photosynthetic performance ${ }^{[18,36,39,53-54]}$. In our study with Chinese broccoli, plants were exposed to different RB-LED ratios: 1) $100: 0$ (0B); 2) $92: 8$ (8B); 3) 84:16 (16B) and, 4) $76: 24$ (24B) under the same photosynthetic photon flux density (PPFD) of $210 \mu \mathrm{mol} / \mathrm{m}^{2} \cdot \mathrm{s}$ and same photoperiod of $12-\mathrm{h}$. Results presented in Table 1 show that Chinese broccoli grown under 16B had the highest $A_{\text {sat }}$ and $g_{s \text { sat }}$ compared to plants grown 0B, 8B and 24B. The 16B is the most suitable combination of RB-LED for Chinese broccoli to achieve the most rapid leaf development with the highest leaf number, total leaf area and leaf mass per unit area (LMA) and greatest stomatal density (SD). Chinese broccoli grown under 16B also had the highest concentration of photosynthetic pigments, soluble and Rubisco proteins on a leaf area basis ${ }^{[21]}$. Thus, these results more conclusively affirm that $16 \mathrm{~B}$ is the most suitable light source to achieve the highest photosynthetic capacities. The highest productivity (shoot fresh weight, FW and dry weight, DW) of Chinese broccoli grown under $16 \mathrm{~B}$ is closely linked to the highest photosynthetic performance on a leaf area basis. Our studies with red- and green-leaved Chinese Basil (P. frutescens) and Na Bai (B. chinensis L.) also showed a similar correlation between photosynthetic performance and productivity under the optimal combination of RB-LED (unpublished data). In the study with cucumber (Cucumis sativus), Hogewoning et al. ${ }^{[39]}$ reported that leaves grown at $7 \%$ blue light and 93\% red light had the highest photosynthetic capacity $\left(A_{\max }\right)$ compared with $0 \%$ blue light and other combination of red and blue lights. The highest $A_{\max }$ associated with the highest LMA and Chl content per leaf area. In another study on cucumber $(C$. sativus), it was reported that blue light promotes maximal photosynthetic capacity associated with leaf development and plant water relations ${ }^{[53]}$. In the indoor plant cultivation of sweet basil (Ocimum basilicum cv. Superbo, Sais seeds, Cesena, Italy), Pennisi et al. (2019) also reported that the greatest biomass production was achieved with the correct combination of RB-LED lightings, which resulted in highest $\mathrm{Chl}$ content, water and energy use efficiency ${ }^{[54]}$. The fact that red light supplemented with blue light which increased productivity is linked to enhanced photosynthetic performance has also been reported in many other plant species. They are wheat plants (Triticum aestivum L.) ${ }^{[14]}$, cucumber (Cucumis sativus) seedlings ${ }^{[19,49]}$, different peppermint species (Mentha piperita, M. spicata, M. longifolia) ${ }^{[32]}$. In the study with lettuce plants (Lactuca sativa L.), blue light could promote photosynthetic performance or growth by stimulating morphological and physiological responses, yet there was no positive correlation between photosynthetic rate and shoot dry weight accumulation ${ }^{[36]}$.

Goins et al. ${ }^{[5]}$ examined the growth of Arabidopsis plants under different combinations of RB-LEDs. When grown under R-LED alone, Arabidopsis leaf morphology was abnormal with the downward curling of leaf margins. However, supplementing any level of B-LED restored normal leaf morphology ${ }^{[55]}$. Although the Chinese broccoli grown under $0 \mathrm{~B}$ were smaller with lower shoot and root productivity, smaller leaf number and total leaf area (Table 1) compared to those grown under combined RB-LEDs, all plants look healthy with minimum overlap expanded leaves, which reflects the maximum light-interception per unit leaf area. Compared to R-LED alone (0B), all combined RB-LEDs promote leaf growth and development, dry matter accumulation and photosynthesis of Chinese broccoli (Figure 1 and Table 1). These results support the notion that for certain species any level of blue light regulates leaf development and photosynthetic performance ${ }^{[18,36]}$. In other words, blue light alleviate "red light syndrome" such as a low photosynthetic rate, low LMA, unresponsive stomatal conductance and impaired shoot and root growth $^{[7,36,39,51]}$. 


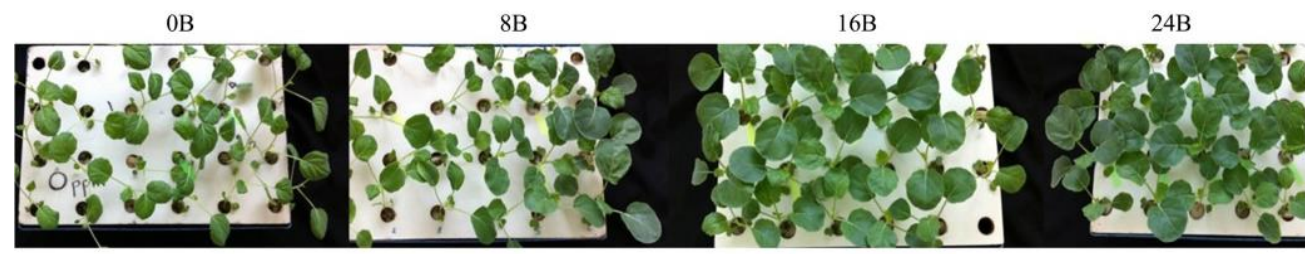

a.

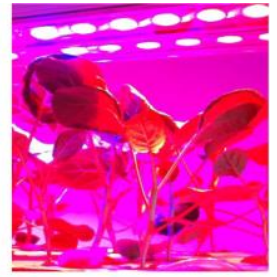

b.

Figure 1 Chinese broccoli (B. alboglabra Bailey) plants grown under different RB-LEDs for $15 \mathrm{~d}$ (a) and under 16B condition for $21 \mathrm{~d}$ (b) (unpublished data)

Table 1 Leaf traits (leaf number, leaf area, leaf matter accumulation, LMA, stomatal density, SD), shoot and root productivity and photosynthetic gas exchange of Chinese broccoli (B. alboglabra) grown under different combinations of RB-LEDs

\begin{tabular}{|c|c|c|c|c|}
\hline \multicolumn{5}{|c|}{ RB-LED light treatments } \\
\hline Parameters & OB & $8 \mathrm{~B}$ & $16 \mathrm{~B}$ & 24B \\
\hline Leaf number & $5.2 \pm 0.19^{\mathrm{c}}$ & $5.4 \pm 0.21^{\mathrm{c}}$ & $7.1 \pm 0.13^{\mathrm{a}}$ & $6.2 \pm 0.17^{b}$ \\
\hline Leaf area $/ \mathrm{cm}^{2}$ & $89.8 \pm 11.6^{\mathrm{d}}$ & $122.5 \pm 12.8^{\mathrm{c}}$ & $198.3 \pm 25.1^{\mathrm{a}}$ & $162.4 \pm 19.2^{b}$ \\
\hline $\mathrm{LMA} /\left(\mathrm{mg} \cdot \mathrm{cm}^{-2}\right)$ & $2.105 \pm 0.06^{\mathrm{d}}$ & $2.614 \pm 0.072^{\mathrm{c}}$ & $3.406 \pm 0.093^{\mathrm{a}}$ & $2.911 \pm 0.086^{\mathrm{b}}$ \\
\hline $\mathrm{SD} /\left(\right.$ Stomata $\left.\cdot \mathrm{mm}^{-2}\right)$ & $157.6 \pm 31.1^{\mathrm{c}}$ & $238.6 \pm 18.3^{\mathrm{b}}$ & $293.2 \pm 24.5^{\mathrm{a}}$ & $291.6 \pm 24.1^{\mathrm{a}}$ \\
\hline Shoot FW/g & $10.12 \pm 0.74^{\mathrm{d}}$ & $13.54 \pm 1.09^{c}$ & $22.17 \pm 0.88^{\mathrm{a}}$ & $16.73 \pm 0.92^{\mathrm{b}}$ \\
\hline Shoot DW/g & $0.542 \pm 0.031^{\mathrm{d}}$ & $0.873 \pm 0.048^{\mathrm{c}}$ & $1.678 \pm 0.062^{\mathrm{a}}$ & $1.179 \pm 0.051^{\mathrm{b}}$ \\
\hline Root FW/g & $0.711 \pm 0.152^{\mathrm{d}}$ & $1.143 \pm 0.135^{\mathrm{c}}$ & $1.726 \pm 0.161^{\mathrm{a}}$ & $1.436 \pm 0.119^{\mathrm{b}}$ \\
\hline Root DW/g & $0.073 \pm 0.011^{\mathrm{d}}$ & $0.121 \pm 0.017^{\mathrm{c}}$ & $0.179 \pm 0.020^{\mathrm{a}}$ & $0.147 \pm 0.018^{b}$ \\
\hline$A_{\text {sat }} /\left(\mu \mathrm{mol} \mathrm{CO}{ }_{2} \cdot \mathrm{m}^{-2} \cdot \mathrm{s}^{-1}\right)$ & $11.65 \pm 0.93^{d}$ & $14.02 \pm 0.85^{\mathrm{c}}$ & $22.15 \pm 1.27^{\mathrm{a}}$ & $17.69 \pm 0.87^{\mathrm{b}}$ \\
\hline$g_{\text {s sat }} /\left(\mathrm{mmol} \mathrm{H} \mathrm{H}_{2} \mathrm{O} \cdot \mathrm{m}^{-2} \cdot \mathrm{s}^{-1}\right)$ & $325 \pm 12.1^{\mathrm{c}}$ & $372 \pm 10.3^{b}$ & $448 \pm 10.9^{\mathrm{a}}$ & $436 \pm 11.6^{\mathrm{a}}$ \\
\hline
\end{tabular}

Note: Parameters of productivity were measured after harvest (that was, 21 days after transplanting) whereas $A_{\text {sat }}$ and $g_{s}$ sat were determine 3 days before harvest. Means with different letters are statistically different $(p<0.05 ; n=7)$ as determined by Tukey's multiple comparison test (Partially modified from He et al. $\left.2015^{[21]}\right)$.

\section{High B:R-LED ratios lead to the decline in productivity but do not affect the photosynthetic performance of ice plants (M. crystallinum)}

It has long been known that the light absorption of photosynthetic pigments is greater in the blue and red regions of the photosynthetically active radiation spectral range ${ }^{[56]}$. However, the red light usually is the basal component to drive photosynthesis. Red light alone is sufficient for normal growth ${ }^{[8,57]}$ because red wavelengths (600 to $700 \mathrm{~nm}$ ) are efficiently absorbed by $\mathrm{Chl}^{[58]}$. Plants grown under blue light have higher total $\mathrm{Chl}$ content $[20,21,39,42,53]$, higher $\mathrm{Chl} \mathrm{a} / \mathrm{b}$ ratio $^{[32,59,60]}$, greater cytochrome $(\mathrm{Cyt}) f^{[59]}$, and Rubisco contents than plants grown under red light ${ }^{[20,31,59,60]}$. Furthermore, Hogewoning et al. ${ }^{[39]}$ reported that the growth of cucumber in the absence of blue light, led to dysfunction of the photosynthetic machinery, in particular a loss of photochemical efficiency of PS II and the maximum photosynthetic capacity per leaf area. However, only $7 \%$ blue light was sufficient to prevent any overt dysfunction in photosynthesis ${ }^{[39]}$. Compared to $0 \%$ blue light, the $A_{\max }$ of cucumber grown at $7 \%$ blue light was two-fold higher and increased with increasing blue light up to $50 \%$. On increasing blue light from 0 to $50 \%$ during growth, the increase in $A_{\max }$ was associated with a greater LMA, higher $\mathrm{N}$ and total $\mathrm{Chl}$ content per leaf are ${ }^{[39]}$. At $100 \%$ blue light, $A_{\max }$ was lower but maximal PS II efficiency was normal (i.e. $\mathrm{F}_{\mathrm{v}} / \mathrm{F}_{\mathrm{m}}$ ratio $>0.8$ ). Our study with Chinese broccoli shows similar responses (Table 1) to increased blue light as cucumber leaves ${ }^{[39]}$. For instance, with increased blue light from 0 to $16 \%$ (16B), the increases in $A_{s a t}\left(=A_{\max }\right)$ also associated with a greater leaf number, leaf area, LMA, SD, shoot and root biomass. However, plants grown under $16 \mathrm{~B}$ and $24 \mathrm{~B}$ had similar values of $g_{s}$ sat but lower $A_{\text {sat }}$ was observed in plants grown under 24B (Table 1). These results imply that higher amounts of blue LED, for instance, 24B may cause some reversible damage on photosynthetic machinery as reflected by healthy $\mathrm{Chl}$ fluorescence $\mathrm{F}_{\mathrm{v}} / \mathrm{F}_{\mathrm{m}}$ ratios of $>0.8$ (data not shown).

In our study with a facultative CAM ice plant ( $M$. crystallinum $)^{[39]}$, impacts of different R:B-LED ratios on the photosynthetic performance and productivity differ from those of cucumber $^{[39]}$ and Chinese broccoli ${ }^{[21]}$. Figure 2a shows ice plants cultured aeroponically in a $16 \mathrm{~h}$ photoperiod at an equal photosynthetic photon flux density (PPFD) of $350 \mu \mathrm{mol} / \mathrm{m}^{2} \cdot \mathrm{s}$ under different RB-LED ratios: 1) 100:0 (0B); 2) 90:10 (10B); 3) 80:20 (20B), 4) 70:30 (30B), 5) 50:50 (50B) and 6) 0:100 (100B) for $14 \mathrm{~d}$ Grown under $10 \mathrm{~B}$ condition, ice plants had the highest shoot and root FW and DW compared to all other plants. No significant differences were observed in shoot and root FW and DW between $20 \mathrm{~B}$ and $30 \mathrm{~B}$ treatments. Plants grown under $0 \mathrm{~B}, 50 \mathrm{~B}$ and $100 \mathrm{~B}$ conditions had similar lower values of shoot, root FW and DW (Figure 3). Our results of ice plants agree with the finding from many other studies that supplementing optimal amount of blue light to red light is necessary to achieve greater biomass accumulation $^{[18,21,29,39,61,62]}$. However, similar to the $0 \mathrm{~B}$ condition the stronger blue-LEDs such as $50 \mathrm{~B}$ and 100B resulted in reduction of biomass accumulation in ice plant (Figure 3 ). In the study with lettuce, Wang et al. ${ }^{[36]}$ studied how the different R:B-LED ratios affected photosynthetic performance. They reported that leaf photosynthetic capacity $\left(A_{\max }\right)$ and photosynthetic rate $\left(P_{n}\right)$ were highest with R:B-LED ratio of 1 but increased with decreasing $\mathrm{R}$ :B-LED ratio (or increasing B-LED percentage). For ice plants, no differences in maximal photosynthetic $\mathrm{O}_{2}$ evolution rate (Figure 4a), $A_{\text {sat }}$, (Figure 4b) and $g_{s \text { sat }}$ (Figure 4c) were observed among plants grown under different R:B-LED ratios although they were significantly higher than those of $0 \mathrm{~B}$ plants. Statistically, ice plants grown under the different R:B-LED ratios had similar values of $P_{n}, A_{s a t}$ and $g_{s a t} . \quad$ In the study with rapeseed (B. napus L.), 
compared to $0 \%$ blue light, except for $100 \%$ B-LED, all other R:B-LED ratios $(25 \%, 50 \%$ and $75 \% \mathrm{~B})$ enhanced photosynthetic capacity $\left(P_{\max }\right)$. These results were similar to our results with ice plants (Figure 4a) except for that fact that rapeseed plants grown under $100 \%$ B-LED had similar lower $P_{\max }$ as $100 \%$ R-LED plants $^{[18]}$. Rapeseed plants grown under $100 \%$ R-LED or $100 \%$ B-LED were stressed with a low photosynthetic maximum quantum yield (lower $\mathrm{F}_{\mathrm{v}} / \mathrm{F}_{\mathrm{m}}$ ratio). However, in our study, all ice plants had $\mathrm{F}_{\mathrm{v}} / \mathrm{F}_{\mathrm{m}}$ ratios of $>0.8$, indicating that no stress occurred in any plants ${ }^{[20]}$

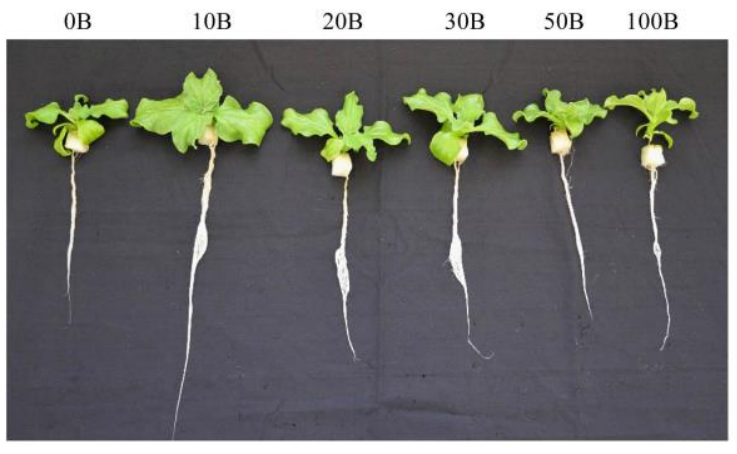

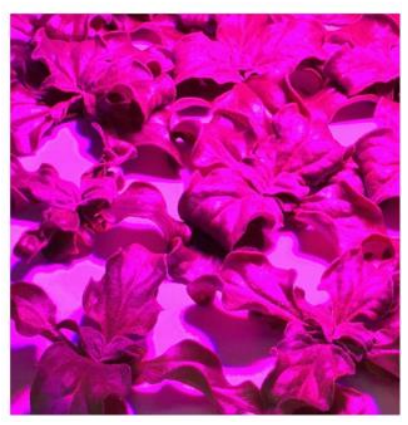

Figure 2 Ice plants (M. crystallinum) grown under different RB-LEDs (a) and under 10B condition for $18 \mathrm{~d}$ (b) (unpublished data)

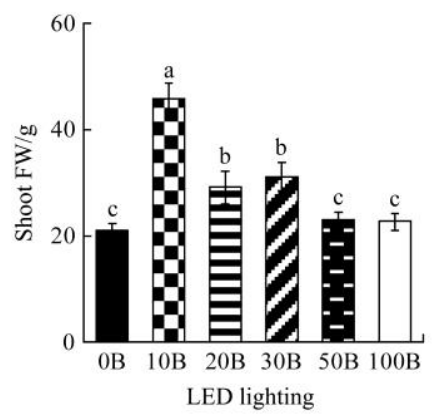

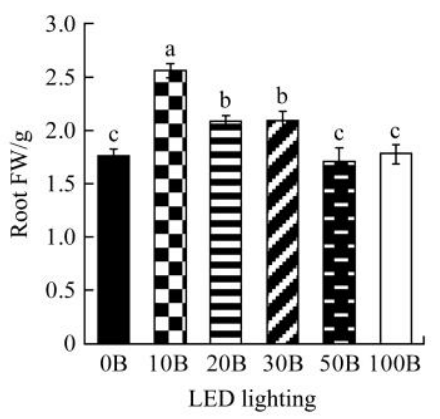

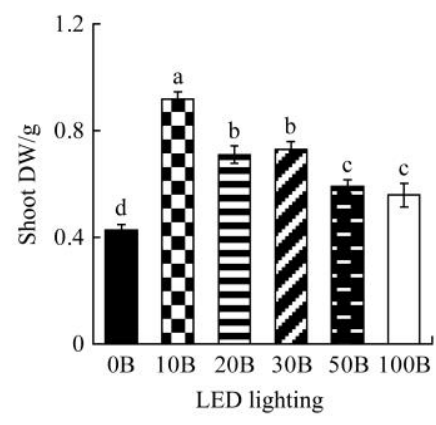

c.

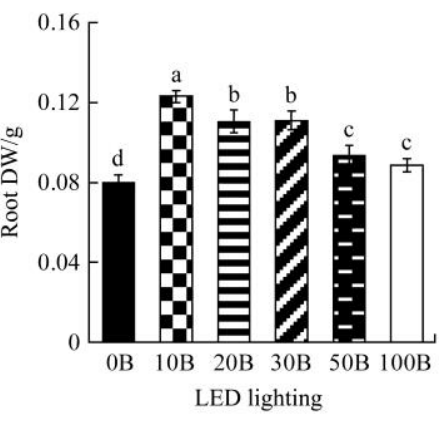

Note: Vertical bars represent the standard errors. Means with different letters are statistically different $(p<0.05 ; n=6)$ as determined by Tukey's multiple comparison test (modified from He et al. 2017 ${ }^{[20]}$ ). The same below.

Figure 3 Shoot FW and DW (a, c), root FW and DW (b, d) of ice plants (M. crystallinum) grown under different R:B-LED ratios for $21 \mathrm{~d}$

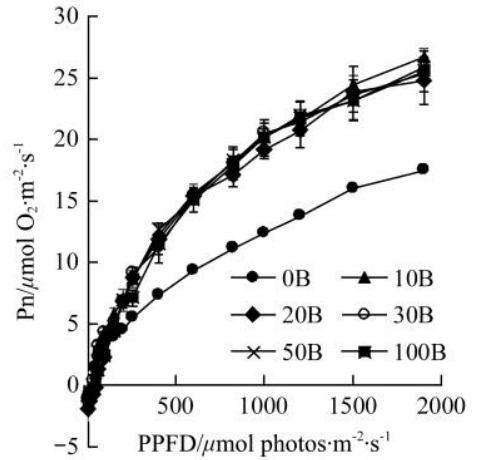

a.

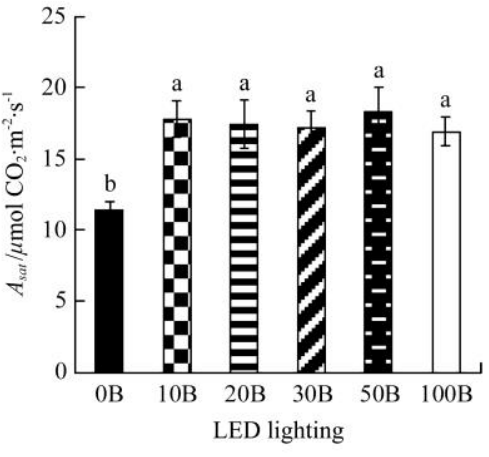

b.

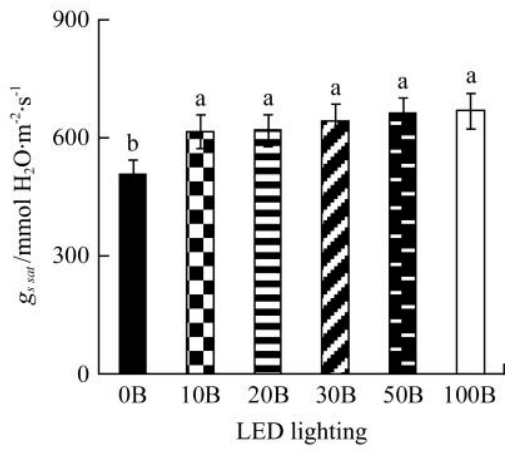

c.

Figure 4 Light response curves of photosynthetic $\mathrm{O}_{2}$ evolution, $P_{n}(\mathrm{a}) ; A_{\text {sat }}(\mathrm{b})$ and $g_{s}$ sat $(\mathrm{c})$ of ice plants $(M$. crystallinum) grown under different R:B-LED ratios for $21 \mathrm{~d}$

In rapeseed plants, it was also found that plants grown under different R:B-LED ratios and 100\% B-LED had higher LMA, SD and total $\mathrm{Chl}$ content compared to those grown under $0 \% \mathrm{~B}-\mathrm{LED}^{[18]}$. These results were similar to our studies with ice plants. Figure 5 shows that all R:B-LED ratios increased total $\mathrm{Chl}$ content, $\mathrm{Chl} \mathrm{a} / \mathrm{b}$ ratio and total carotenoids (Car) content to a similar higher level compared to those ice plants grown under $\mathrm{OB}$ condition. However, there is no difference in $\mathrm{Chl} / \mathrm{Car}$ ratio among ice plants grown under different R:B-LED ratios (data not shown). It was also reported that blue light affects $\mathrm{Chl}$ a/b-binding protein of PS II, and photosynthetic electron transport ${ }^{[36,59,63,64]}$. Chl or Car absorb blue light for the formation of 'sun-type' chloroplasts ${ }^{[59]}$. For ice plants, 10B was sufficient to stimulate 'sun-type' photosynthetic characteristic $^{[65]}$ at a rather low irradiance (red:blue LED; 315:35 $\mu \mathrm{mol}$ photon $\left./ \mathrm{m}^{2} \cdot \mathrm{s}\right)^{[20]}$. Grown under R-LED alone (i.e. $0 B$ ), ice plants exhibited the characteristics of low-light-grown plants with lower $P_{n}$ (Figure $4 \mathrm{a}$ ) and $A_{\text {sat }}$ (Figure 4b), less total soluble protein and Rubisco protein (data not shown) ${ }^{[20]}$.

In the study with tomato (Solanum lycopersicum) seedlings, it was reported that the plant height was reduced under blue light, but the $\Phi$ PSII and ETR were enhanced ${ }^{[31]}$. In ice plants, photochemical quenching (qP, Figure 6a) and ETR (Figure 6b) measured under actinic light of $335 \mu \mathrm{mol}$ photon $/ \mathrm{m}^{2} \cdot \mathrm{s}$ that was close to the growth irradiance of all plants, were significantly 
higher in all plants grown under the different R:B-LED ratios compared to those grown under $\mathrm{OB}$ condition ${ }^{[20]}$. Higher $\mathrm{qP}$ and ETR values of ice plants resulted from enhanced photosynthetic utilization of radiant energy due to the greater amount of total $\mathrm{Chl}$ contents and higher $\mathrm{Chl} \mathrm{a} / \mathrm{b}$ ratios (Figures $5 \mathrm{a}$ and $5 \mathrm{~b}$ ). Higher B-LEDs (20B, 30B, 50B and 100B) also resulted in higher NPQ in ice plants (Figure 6c). Higher level of blue light may damage PS II and ice plants increased NPQ to protect themselves against excess excitation energy through $\mathrm{Car}^{[66-69]}$. Recently, it was reported that cyclic electron flow (CEF) which generates a $\mathrm{pH}$ gradient $(\Delta \mathrm{pH})$ across thylakoid membrane triggers the protective process of NPQ under stress conditions ${ }^{[70]}$. The CEF around PSI is another mechanism for dissipating excess photon energy ${ }^{[71-75]}$.
Higher ETR values of ice plants grown under higher levels B-LED (Figure $6 \mathrm{~b}$ ) could be partially due to CEF around PSI that is essential for protecting both PS I and PS II from the damage ${ }^{[73,74,76,77]}$. Red light alone inhibited electron transport from PS II donor side to PS I in cucumber ${ }^{[51]}$ whereas decreased $\mathrm{F}_{\mathrm{v}} / \mathrm{F}_{\mathrm{m}}$ ratio was observed in lettuce exposed to $100 \% \mathrm{~B}^{-\mathrm{LED}^{[36]}}$. However, all ice plants had $\mathrm{F}_{\mathrm{v}} / \mathrm{F}_{\mathrm{m}}$ ratios of $>0.8$ regardless of $\mathrm{R}$ :B-LED ratios including $0 \mathrm{~B}$ condition (data not shown). This result suggests that ice plants grown under higher levels of B-LED could had spent more energy to protect them from photodamage and/or recover from photodamage and thus decreased productivity (Figure 3).

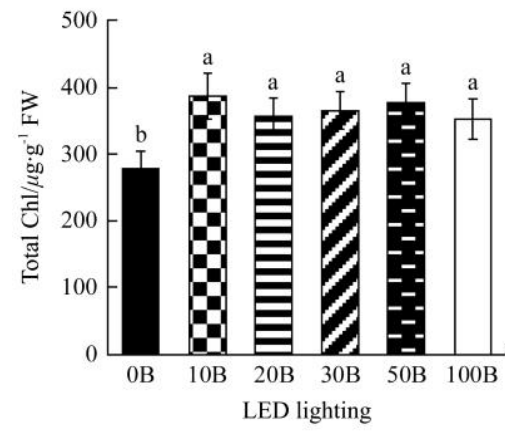

a.

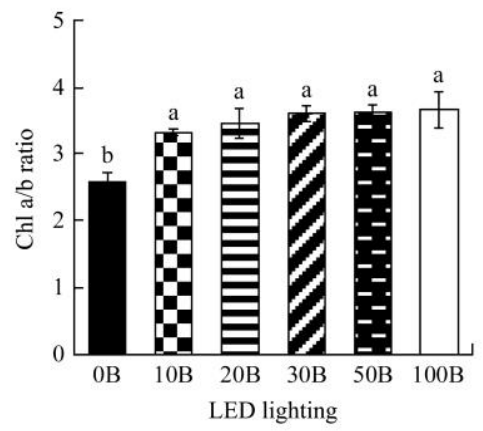

b.

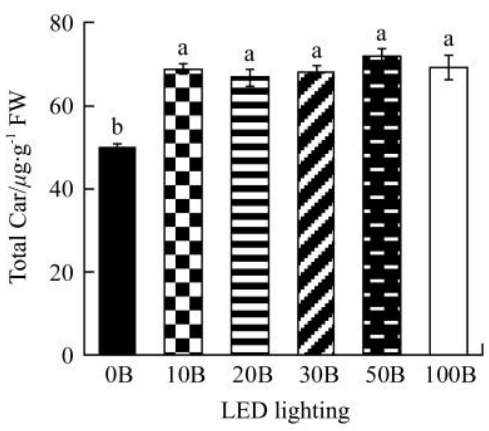

Figure 5 Total Chl content (a), Chl a/b ratio (b) and total Car content (c), of ice plants (M. crystallinum) grown under different R:B-LED

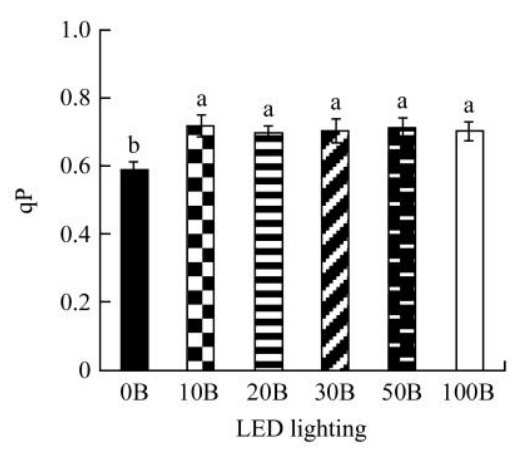

a.

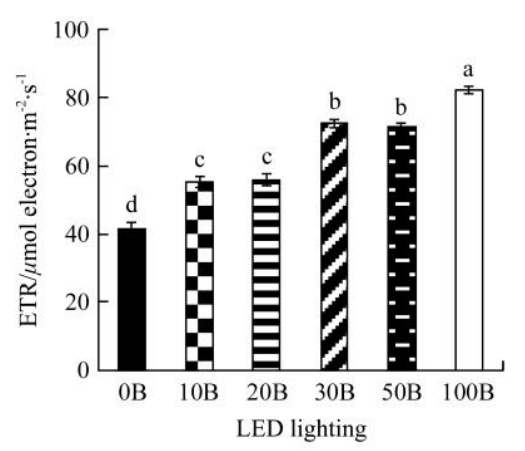

b.

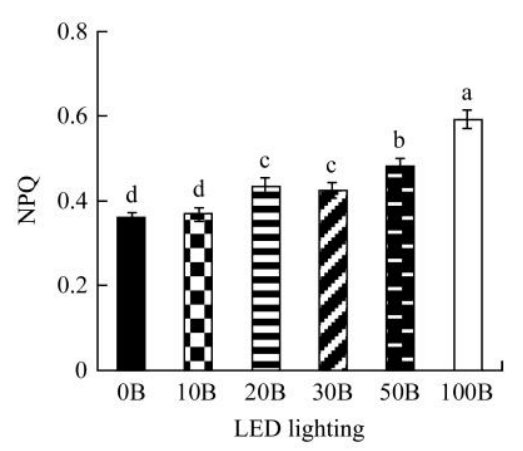

c.

Figures 6 qP (a), ETR (b) and NPQ measured at a PPFD of $335 \mu \mathrm{mol}$ photon $/ \mathrm{m}^{2} \cdot \mathrm{s}$ from ice plants (M. crystallinum) grown under different R:B-LED ratios for $21 \mathrm{~d}$. Each bar is the mean of 20 measurements of 4 different leaves from 4 different plants

\section{Productivity is closely associated with leaf traits} not photosynthetic performance of lettuce ( $L$. sativa $L$. cv. Canasta) grown under different qualities of LEDs

With a focus on our studies of Chinese broccoli and ice plants, this paper has discussed how different R:B-LED ratios affected photosynthesis and productivity in the previous sections. Although the optimal R:B-LED ratio is species-dependent, generally combined RB-LED is more effective than R-LED or B-LED alone in enhancing photosynthesis and thus productivity. This section discusses the impacts of R-LED, supplemented green (G)-LED to R-LED, and combined RB-LED on lettuce ( $L$. sativa $\mathrm{L}$. cv. Canasta).

All lettuce plants were exposed to an equal PPFD of $230 \mu \mathrm{mol} / \mathrm{m}^{2} \cdot \mathrm{s}$ (16-h photoperiod) under each of the six combined LED ratios: $100 \%$ red (0B); $80 \%$ red and $20 \%$ green (20G); $90 \%$ red and $10 \%$ blue $(10 \mathrm{~B}) ; 80 \%$ red and $20 \%$ blue (20B); $50 \%$ red and $50 \%$ blue (50B); and $100 \%$ blue (100B). Figure 7 shows the lettuce plants grown under different LEDs for
$21 \mathrm{~d}$ after transplanting. Compared to plants grown under $0 \mathrm{~B}$ and $20 \mathrm{G}$ conditions, plants grown under different R:B-LED ratios were greener with some red pigment (Figure 7) but lower shoot FW (Figure 8a), smaller total leaf area (Figure 8b). However, all plants had similar leaf number except for those grown under $100 \mathrm{~B}$ plants with smaller number of leaves (Figure 8c). These results indicate that B-LED inhibited leaf expansion but not leaf emergence of lettuce (L. sativa L. cv. Canasta). The results also agree with that red light supplemented with blue light could prevent elongation growth and leaf expansion reported in two different Lactuca recombinant inbred lines (RILs) by our research team ${ }^{[16]}$, cucumber ${ }^{[34]}$ and tomato seedlings ${ }^{[35]}$. However, in our studies with Chinese broccoli ${ }^{[21]}$ and ice plants ${ }^{[20]}$, it was found that the highest shoot productivity associated with a greater leaf number and a rapid leaf area development when $16 \%$ and $10 \%$ of B-LED was added to R-LED, respectively.

In a study with lettuce (L. Sativa 'Waldmann's Green'), Kim et al. ${ }^{[24]}$ reported that green light enhanced growth when it was supplemented to combined red and blue light. Study with another 
lettuce variety (L. sativa L. var. youmaicai), Liu et al. ${ }^{[28,29]}$ also reported that green light added to a wide spectral LED light increased shoot dry mass, total Chl content, light absorptance and $\mathrm{CO}_{2}$ assimilation. However, other researchers reported that monochromic green light at low intensity inhibited plant growth, especially at the seedling stage of lettuce ${ }^{[30]}$ and tomato ${ }^{[31]}$. Experiments with the seedling stage of red leaf lettuce ( $L$. sativa $\mathrm{L}$. cv Banchu Red Fire), different monochromic G-LEDs with different peak wavelengths such as $510 \mathrm{~nm}, 520 \mathrm{~nm}$ and $530 \mathrm{~nm}$ (named G510, G520, G530) were used at different photosynthetic photon flux (PPF) of 100, 200 and $300 \mu \mathrm{mol} / \mathrm{m}^{2} \cdot \mathrm{s}^{[30]}$. Compared with white fluorescence light, lettuce grown at low PPF 100, all G-LEDs decreased shoot growth. Shoot growth under $510 \mathrm{~nm}$ at PPF300 was the highest among all treatments. Leaf photosynthetic rate $\left(P_{n}\right)$ of plants under G-LED at PPF 200 was significantly higher compared to those at PPF100. Plants grown with G510 had the highest $P_{n}$ among all light sources. These results indicated that short wavelength of G510 at higher intensities increased the growth and $P_{n}$. With higher PPF the green light would penetrate into the leaves, be absorbed in chloroplast and drive the photosynthesis enough to growth ${ }^{[30]}$. Based on the above discussion, it seems that the impacts of G-LED on plant growth depend on not only the variety but also the wavelength, the intensity of G-LED and the other LED-spectra to which G-LED was supplemented. The effects of green light supplemented to combined red and blue light or green light alone on plant growth and physiology have been investigated and discussed above. However, there is no report of plants being cultivated under G-LED supplemented to R-LED only. Our study with lettuce ( $L$. sativa $\mathrm{L}$. cv. Canasta), grown under 20\% G-LED (20G at wavelength $517 \mathrm{~nm}$ ) and $80 \%$ R-LED had similar higher values of shoot FW and DW (data not shown), total leaf area as those plants grown under $100 \%$ R-LED (0B) compared to any combined R:B-LED ratio (Figure 8). These results indicate that lettuce plants absorbed the $20 \%$ G-LED for growth. However, lettuce (L. sativa L. cv. Canasta) grown under $0 \mathrm{~B}$ and 20G had lower contents of total Chl (Figure 9a) and Car (data not shown), and lower net maximal photosynthetic rate $\left(\right.$ Net $\left.P_{\max }\right)$ on a leaf area basis measured under saturated light (Figure 9b) compared to those plants grown under all combined R:B-LED. The results also showed that combined RB-LEDs enhanced other photosynthetic performance while $0 \mathrm{~B}$ and $20 \mathrm{G}$ conditions had inhibitory effects. For example, the maximum quantum efficiency of PS II $\left(\mathrm{F}_{\mathrm{v}} / \mathrm{F}_{\mathrm{m}}\right.$ ratio) was the lowest under $0 \mathrm{~B}$ and $20 \mathrm{G}$ (Figure 9c). Cucumber ${ }^{[30]}$ and tomato seedling leaves ${ }^{[31]}$ developed under red light or green light alone was also shown lower $\mathrm{F}_{\mathrm{v}} / \mathrm{F}_{\mathrm{m}}$ ratio. The concentrations of PS II, Cyt $b_{6} f$, total soluble protein and Rubisco protein, ETR and $\mathrm{qP}$ increased with increasing $\mathrm{B}-\mathrm{LED}$ in those plants grown under different R:B-LED ratios while $0 \mathrm{~B}$ and $20 \mathrm{G}$ plants had the lowest values (data not shown). It is well known that biomass accumulation and plant growth strongly depends on net photosynthesis and photosynthetic performance ${ }^{[14,32,36,49,78,79]}$. However, these correlations were not observed in lettuce (L. sativa L. cv. Canasta) grown under different LED qualities (Figures 8a, $9 \mathrm{~b}$ and $9 \mathrm{c})$.

It was reported that leaf growth determines light interception area which is an important parameter in determining plant productivity $^{[80-82]}$. Figure 10a shows the light interception areas measured from the same plants that were used for the measurements of total leaf area (Figure 8b). Plants grown under $\mathrm{OB}$ and $20 \mathrm{G}$ conditions had the largest light interception areas followed by those grown under 10B and 20B conditions. Lettuce plants grown under 50B and 100B conditions had the smallest light interception areas. By comparing the total leaf areas (Figure 8b) and light interception areas (Figure 10a), it was found that leaves grown under $0 \mathrm{~B}$ and $20 \mathrm{G}$ had similar greatest values due to their large elongated and non self-shading expanded leaves (Figure 7). Those plants grown under 50B and 100B also had similar values of total leaf area and light interception area but due to their smallest non-self-shading leaves (Figure 7). However, due to some self-shading, plants grown under $10 \mathrm{~B}$ and $20 \mathrm{~B}$, had light interception areas of $271 \mathrm{~cm}^{2}$ and $286 \mathrm{~cm}^{2}$, respectively (Figure 10a) and they were significant lower than the total leaf areas of $328 \mathrm{~cm}^{2}$ and $322 \mathrm{~cm}^{2}$ (Figure $8 \mathrm{~b}$ ). Light interception area could predict the whole plant carbon gain ${ }^{[80-82]}$. Figure 10c shows the photosynthetic capacities (PA) that were calculated from: $\mathrm{PA}=$ Gross $P_{\max } \times$ total light interception area per plants $\times$ absorptance (Figure 10b). Although they had lower absorptance compared to those plants grown under RB-LEDs (Figure 10b), on a whole plant basis, $0 \mathrm{~B}$ and $20 \mathrm{G}$ plants had the highest PA which was mainly due to the highest light interception area (Figure 10a). For plants grown under $10 \mathrm{~B}$ and $20 \mathrm{~B}$, the higher values of PA resulted from both larger light interception area and higher absorptance. For those 50B and 100B plants, they had the smallest light interception area and thus the lowest PA. The above results indicate the importance of whole plant photosynthetic capacities instead of photosynthetic rate on a leaf area basis (Figure 9b), which is closely linked to the leaf traits in determining the final productivity.

There are tremendous morphological variations such as leaf length, shape, size, color, and heading type in different types of lettuce $^{[83]}$. Leaf anatomical structure that closely related to photosynthetic performance also varies greatly among and within plant species under different environmental conditions ${ }^{[84-86]}$. Different LED spectral qualities further modify the plant morphological and anatomical features of different types of lettuce $^{[3,6,24,28,36,40,42,83]}$. Leaf functional traits including both morphological and anatomical traits determine not only the quantity of light interception but also the photosynthetic capacity and partitioning of photoassimilated carbon ${ }^{[87]}$. Engineering leaf functional traits to optimize light interception and to improve photosynthetic performance has been reported in rice ${ }^{[88]}$ and wheat ${ }^{[89]}$. In a study with Eustoma, Roni et al. ${ }^{[86]}$ reported that both quality and quantity of LEDs resulted in the changes of photosynthetic performance, and phenotypic variations of leaf morphology and anatomy. Using the loose-headed lettuce variety "United States greatly fast growing lettuce", Zhang et al. ${ }^{[90]}$ reported that lettuce phenotype and nutritional quality were significantly changed under different LED lights. By controlling all other environmental conditions, it is feasible for a smart plant factory with artificial light (PFAL) to screen and to improve leaf functional traits in relation to their photosynthetic performance through manipulating LED conditions. Although it remains a challenge, using high-throughput plant phenotyping infrastructure corresponding principles for phenotype data analysis ${ }^{[91]}$, the PFAL has a capability of phenotyping of leaf functional traits of different leafy vegetables to improve both productivity and quality on a large scale $^{[92]}$. 


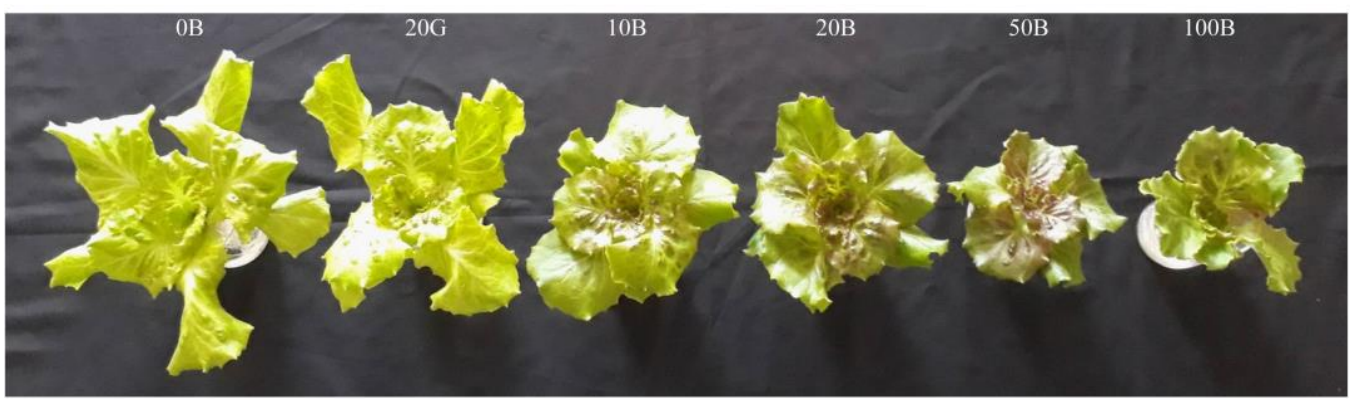

Figure 7 Lettuce (L. sativa L. cv. Canasta) grown under different combined LED lighting conditions for $21 \mathrm{~d}$. $100 \%$ red $(0 \mathrm{~B}) ; 80 \%$ red and $20 \%$ green $(20 \mathrm{G}) ; 90 \%$ red and $10 \%$ blue $(10 \mathrm{~B}) ; 80 \%$ red and $20 \%$ blue (20B); $50 \%$ red and $50 \%$ blue (50B); and 100\% blue (100B) (unpublished data)

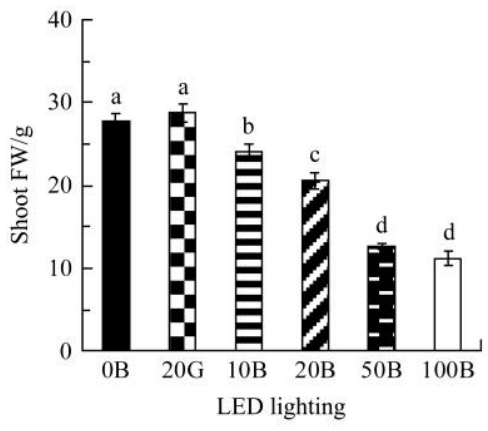

a.

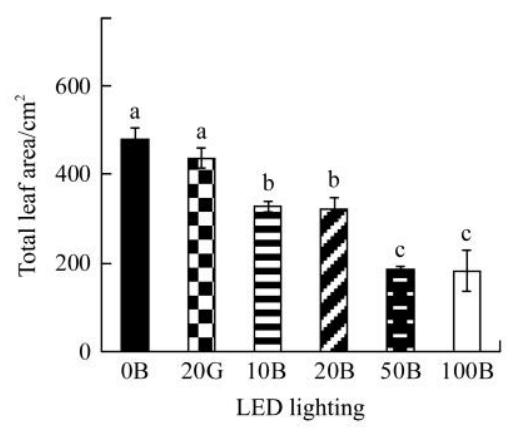

b.

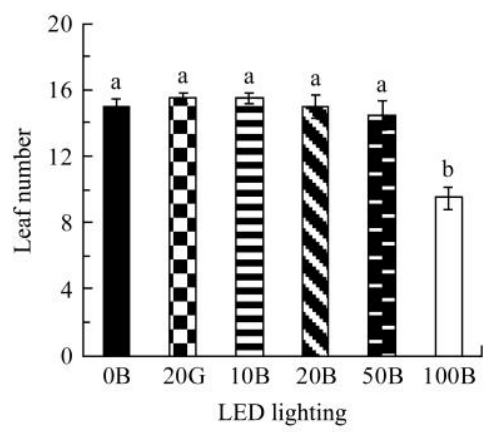

c.

Note: Vertical bars represent the standard errors. Means with different letters are statistically different (unpublished data).

Figure 8 Shoot FW (a), total leaf area (b) and leaf number (c) of L. sativa (cv. Canasta) grown under different LED lightings for 21 d

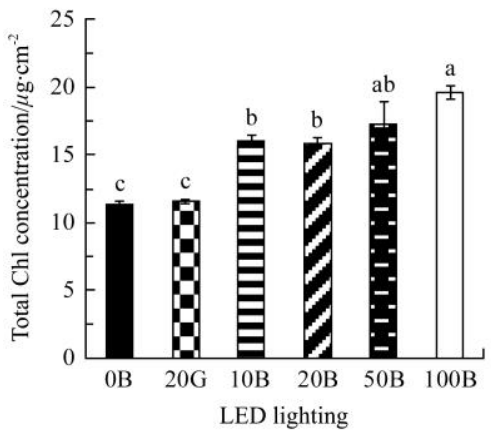

a.

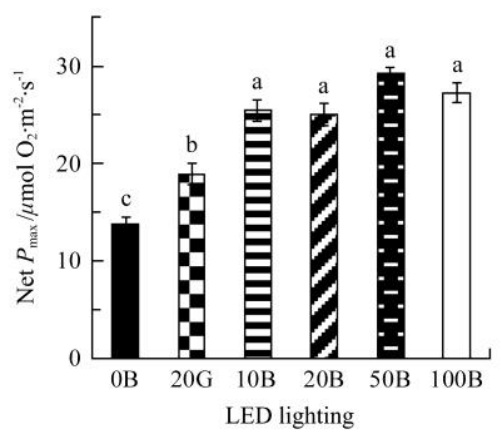

b.

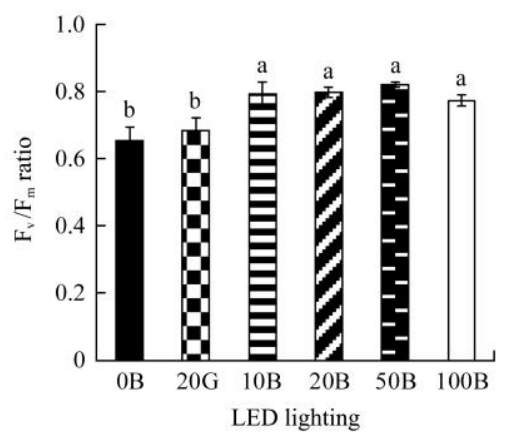

c.

Note: Vertical bars represent the standard errors. Means with different letters are statistically different (unpublished data).

Figure 9 Total Chl content (a), Net $P_{\max }(\mathrm{b})$ and $\mathrm{F}_{\mathrm{v}} / \mathrm{F}_{\mathrm{m}}$ ratio (c) of lettuce (L. sativa L. cv. Canasta) grown under different LED lightings for $21 \mathrm{~d}$

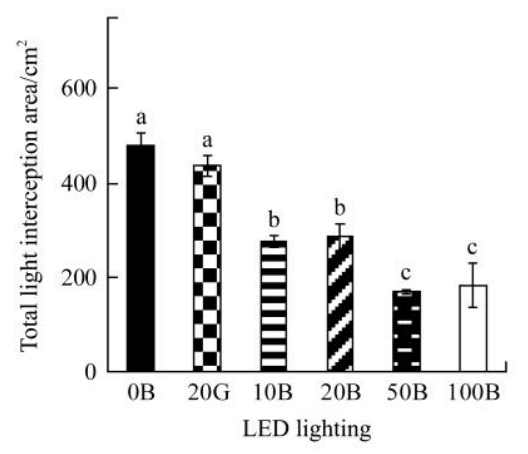

a.

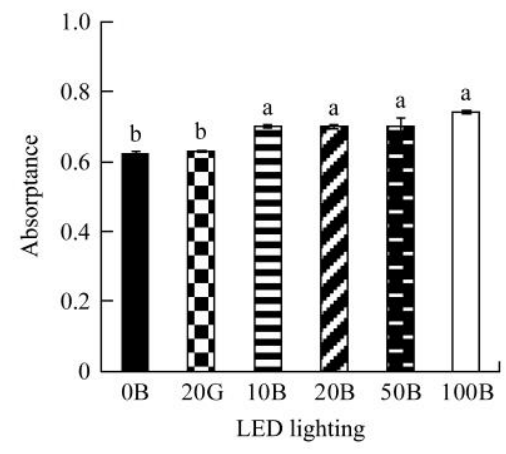

b.

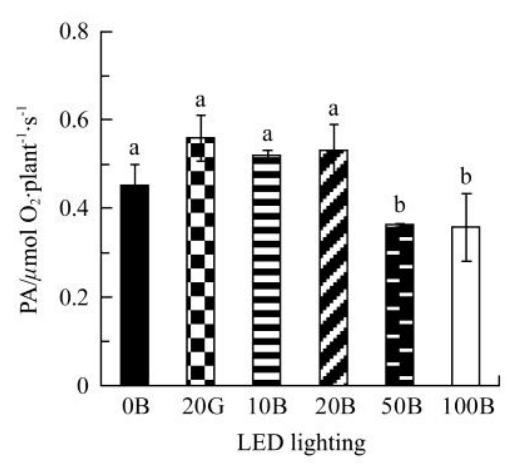

c.

Note: Vertical bars represent the standard errors. Means with different letters are statistically different (unpublished data).

Figure 10 Light interception area (a), absorptance (b) and photosynthetic capacity, PA (c) of lettuce (L. sativa L. cv. Canasta) grown under different LED lightings for $21 \mathrm{~d}$

\section{Conclusions}

Although the optimal R:B-LED ratio is species-dependent, generally, optimal combined RB-LED is more effective than
R-LED or B-LED alone in enhancing photosynthesis and thus productivity. The impacts of G-LED on photosynthetic performance and productivity depend on not only plant species but also its wavelength, intensity and the combination of G-LED with 
other LED spectra. Productivity is closely linked to photosynthetic performance on a leaf area basis when plants have the maximum light-interception per unit leaf area. Otherwise, leaf traits such as light interception area and absorptance are important factors in determining the whole plant photosynthetic capability that is associated with productivity.

\section{Acknowledgements}

We thank the Singapore Millennium Foundation (SMF-Farming System) and Nanyang Technological University (NTU AcRF Tier 1, RP 1/18 HJ) for their financial support.

This manuscript was presented at 2019 International Symposium on Environment Control Technology for Value-added Plant Production hold in Beijing from Aug. 27-29, 2019.

\section{[References]}

[1] He J. Farming of vegetables in space-limited environment. COSMOS, 2015; 11: 21-36. doi: 10.1142/S0219607715500020

[2] He J. Integrated vertical aeroponic farming system for vegetable production in space limited environments. Acta Horticultura, 2017; 1176: 25-35. doi: 10.17660/ ActaHortic.2017.1176.5

[3] Touliatos D, Dodd I C, McAinsh M. Vertical farming increases lettuce yield per unit area compared to conventional horizontal hydroponics. Food and Energy Security, 2016; 6: 184-191. doi: 10.1002/fes3.83

[4] Kozai T, Niu G. In: Kozai T, Niu G, Takagaki M (Ed.), Challenges for the next-generation PFAL. Plant factory: An indoor vertical farming system for efficient quality food production. Academic Press Elsevier: Amsterdam. The Netherlands, 2016; pp. 387-393.

[5] Heo J, Lee C, Chakrabarty D, Paek K. Growth responses of marigold and salvia bedding plants as affected by monochromic or mixture radiation provided by a Light-Emitting Diode (LED). Plant Growth Regulation, 2002; 38: 225-230. doi: 10.1023/A:1021523832488.

[6] Loconsole D, Cocetta G, Santoro P, Ferrante A. Optimization of LED lighting and quality evaluation of romaine lettuce grown in an innovative indoor cultivation system. Sustainability; 2019; 11: 841. doi: 10.3390/su11030841

[7] Trouwborst G, Oosterkamp J, Hogewoning S W, Harbinson J, Van Ieperen W. The responses of light interception, photosynthesis and fruit yield of cucumber to LED-lighting within the canopy. Physiologia Plantarum, 2010; 138: 289-300. doi: 10.1111/j.1399-3054.2009.01333.x

[8] Olle M, Viršile A. The effects of light-emitting diode lighting on the greenhouse plant growth and quality. Agricultural and Food Science, 2013; 22: 223-234. doi: 10.23986/afsci.7897

[9] Darko E, Heydarizadeh P, Schoefs B, Sabzalian M R. Photosynthesis under artificial light: the shift in primary and secondary metabolism. Philosophical Transactions of the Royal Society B, 2014; 369: 20130243. doi: 10.1098/rstb.2013.0243

[10] Agarwal A, Gupta S D. Impact of light-emitting diodes (LEDs) and its potential on plant growth and development in controlled-environment plant production system. Current Biotechnology, 2016; 5(1): 28-43. doi: 10.2174/2211550104666151006001126

[11] Benke K, Tomkins B. Future food-production systems: vertical farming and controlled-environment agriculture. Sustainability: Science, Practice and Policy, 2017; 13 (1): 13-26. doi: 10.1080/15487733.2017.1394054

[12] Brown C S, Schuerger A C, Sager J C. Growth and photomorphogenesis of pepper plants under red light-emitting diodes with supplemental blue or far-red lighting. Journal of the American Society for Horticultural Science, 1995; 120: 803-813.

[13] Schuerger A C, Brown C S, Stryjewski E C. Anatomical features of pepper plants (Capsicum annuиm L.) grown under red light-emitting diodes supplemented with blue or far-red light. Annuals of Botany (London), 1997; 79: 273-282. doi: 10.1006/anbo.1996.0341

[14] Goins G D, Yorio N C, Sanwo M M, Brown C S. Photomorphogenesis, photosynthesis, and seed yield of wheat plants grown under red light-emitting diodes (LEDs) with and without supplemental blue lighting. Journal of Experimental Botany, 1997; 48: 1407-1413. doi: $10.1093 / \mathrm{jxb} / 48.7 .1407$
[15] Yorio N D, Goins G D, Kagie H R, Wheeler R M, Sager J C. Improving spinach, radish and lettuce growth under red light-emitting diodes (LEDs) with blue light supplementation. HortScience, 2001; 36: 380-383. doi: 10.21273/HORTSCI. 36.2.380

[16] Choong T W, He J, Qin L, Lee S K. Quality of supplementary LED lighting effects on growth and photosynthesis of two different Lactuca recombinant inbred lines (RILs) grown in a tropical greenhouse. Photosynthetica, 2018; 56: 1278-1286. doi: 10.1007/s11099-018-0828-2.

[17] Nhut D T, Takamura, T, Watanabe H, Okamoto K, Tanaka M. Responses of strawberry plantlets cultured in vitro under super bright red and blue light-emitting diodes (LEDs). Plant Cell Tissue Organ Culture, 2003; 73 : 43-52. doi: 10.1023/A:1022638508007

[18] Shengxin C, Chunxia L, Xuyang Y, Song C, Xuelei J, Xiaoying L, et al Morphological, photosynthetic, and physiological responses of rapeseed leaf to different combinations of red and blue lights at the rosette stage. Frontier in Plant Science, 2016; 7: 1144. doi: 10.3389/fpls. 2016.01144

[19] Hernández R, Kubota C. Physiological responses of cucumber seedlings under different blue and red photon flux ratios using LEDs. Environmental and Experimental Botany, 2016; 121: 66-74. doi: 10.1016/j.envexpbot. 2015.04.001

[20] He J, Qin L, Chong E L C, Choong T W, Lee S K. Plant growth and photosynthetic characteristics of Mesembryanthemum crystallinum grown aeroponically under different blue- and red-LEDs. Frontier in Plant Science, 2017; 8: 361. doi: 10.3389/fpls.2017.00361

[21] He J, Qin L, Liu Y, Choong T W. Photosynthetic capacities and productivity of indoor hydroponically grown Brassica alboglabra Bailey under different light sources. American Journal of Plant Sciences, 2015 6(4): 228-239. doi: 10.4236/ajps.2015.64060

[22] He J, Qin L, Teo L J L, Choong T W. Nitrate accumulation, productivity and photosynthesis of Brassica alboglabra grown under low light with supplemental LED lighting in the tropical greenhouse. Journal of Plant Nutrition, 2019; 42(15): 1740-1749. doi: 0.1080/01904167.2019.1643367

[23] Li H, Tang C, Xu Z. The effects of different light qualities on rapeseed (Brassica napus L.) plantlet growth and morphogenesis. Scientia Horticulturae, 2013; 150: 117-124. doi: 10.1016/j.scienta.2012.10.009

[24] Kim H H, Goins G D, Wheeler R M, Sager J C. Green-light supplementation for enhanced lettuce growth under red- and blue-light-emitting diodes. HortScience, 2004; 39: 1617-1622. doi: 10.21273/HORTSCI.39.7.1617

[25] Folta K M, Koss L L, McMorrow R, Kim H-H, Kenitz J D, Wheeler R, et al. Design and fabrication of adjustable red-green-blue LED light arrays for plant research. BMC Plant Biology, 2005; 5: 17 . doi: 10.1186/1471-2229-5-17

[26] Folta K M, Maruhnich S A. Green light: a signal to slow down or stop. Journal of Experimental Botany, 2007; 58: 3099-3111. doi: 10.1093/jxb/erm130

[27] Terashima I, Fujita T, Inoue T, Chow W S, Oguchi R. Green light drives leaf photosynthesis more efficiently than red light in strong white: Revisiting the enigmatic question of why leaves are green. Plant Cell Physiology, 2009; 50, 684-697. doi: 10.1093/pcp/pcp034.

[28] Liu H, Fu Y, Wang M, Liu H. Green light enhances growth, photosynthetic pigments and $\mathrm{CO}_{2}$ assimilation efficiency of lettuce as revealed by 'knock-out' of the 480-560 nm spectral waveband. Photosynthetica, 2017; 55(1): 144-152.

[29] Liu H, Fu Y, Hu D, Yu J, Liu H. Effect of green, yellow and purple radiation on biomass, photosynthesis, morphology and soluble sugar content of leafy lettuce via spectral wavebands "knock out". Scientia Horticulture, 2018; 236: 10-17. doi: 10.1016/j.scienta.2018.03.027

[30] Johkan M, Shoji K, Goto F, Hahida S, Yoshihara T. Effect of green light wavelength and intensity on photomorphogenesis and photosynthesis in Lactuca sativa. Environmental and Experimental Botany, 2012; 75: 128-133. doi: 10.1016/j.envexpbot.2011.08.010

[31] Wu Q, Su N, Shen W, Cui J. Analyzing photosynthetic activity and growth of Solanum lycopersicum seedlings exposed to different light qualities. Acta Physiologiae Plantarum 2014; 36: 1411-1420. doi: 10.1007/s11738-014-1519-7

[32] Sabzalian M, Heydarizadeh P, Zahedi M, Boroomand A, Agharokh M, Sahba M, 'Schoefs B. High performance of vegetables, flowers, and medicinal plants in a red-blue LED incubator for indoor plant production. Agronomy Sustainable Development, 2014; 34(14): 879-886. doi: 10.1007/s13593-014-0209-6 
[33] Zheng L, Van Labeke M C. Chrysanthemum morphology, photosynthetic efficiency and antioxidant capacity are differentially modified by light quality. Journal of Plant Physiology, 2017; 213: 66-74. doi: 10.1016/j.jplph. 2017.03.005

[34] Novičkovas A, Brazaitytė A, Duchovskis P, Jankauskienė J, Samuolienė G, Virsilè A, Sirtautas R, Bliznikas Z, Zukauskas A. Solid-state lamps (LEDS) for the short-wavelength supplementary lighting in greenhouse: Experimental results with cucumber. Acta Horticulturae, 2012; 927: 723-730. doi: 10.17660/ActaHortic.2012.927.90

[35] Nanya K, Ishigami Y, Hikosaka S, Goto E. Effects of blue and red light on stem elongation and flowering of tomato seedlings. Acta Horticulturae, 2012; 956: 261-266. doi: 10.17660/ActaHortic.2012.956.29

[36] Wang J, Lu W, Tong Y, Yang Q, Leaf morphology, photosynthetic performance, chlorophyll fluorescence, stomatal development of lettuce (Lactuca sativa $\mathrm{L}$.) exposed to different ratios of red light to blue light. Frontier in Plant Science, 2016; 7: 250. doi: 10.3389/fpls.2016.00250

[37] Wang S, Wang X, Shi X, Wang B, Liu F. Red and blue lights significantly affect photosynthetic properties and ultrastructure of mesophyll cells in senescing grape Leaves. Horticultural Plant Journal, 2016; 2 (2): 82-90. doi: 10.1016/j.hpj.2016.03.001

[38] Mizuno T, Amaki W, Watanabe H. Effects of Monochromatic Light irradiation by LED on the growth anthocyanin contents in leaves of cabbage seedlings. Acta Horticulturae, 2011; 907: 179-184. dio: 10.17660/ActaHortic. 2011.907.25

[39] Hogewoning S, Trouworst G, Maljaars H, Poorter H, van leperen W, Harbinson J. Blue light dose-response of leaf photosynthesis, morphology, and chemical composition of cucumis sativus grown under different combinations of red and blue light. Journal Experimental Botany, 2010; 61: 3107-3117. doi: 10.1093/jxb/erq132

[40] Muneer, S., Kim E J, Park J S, and Lee J H (2014). Influence of green, red and blue light emitting diodes on multiprotein complex proteins and photosynthetic activity under different light intensities in lettuce leaves (Lactuca sativa L.). International Journal of Molecular Sciences, 2014; 15: 4657-4670. doi: 10.3390/ijms 15034657

[41] Bukhov N G, Drozdova I S, Bondar V V. Light response curves of photosynthesis in leaves of sun-type and shade-type plants grown in blue or red light. Journal of Photochemistry and Photobiology B: Biology, 1995; 30: 39-41. doi: 10.1016/1011-1344(95)07124-K

[42] Dougher T A, Bugbee B. Evidence for yellow light suppression of lettuce growth. Photochemistry and Photobiology, 2001; 73: 208-212. doi: 10.1562/ 0031-86552001073<0208:EFYLSO<2.0.CO;2

[43] Klein R M. Effect of green light on biological systems. Biological Reviews Cambridge Philosophical Society, 1992; 67: 199-284. doi: 10.1111/j.1469-185X.1992.tb01019.x

[44] He J, Lee S K. Impact of climate change on food security and proposed solutions for the modern city. Acta Horticulturae, 2012; 1004: 41-52. doi: 10.17660/ActaHortic.2013.1004.3

[45] He J, Lim L I, Qin L. Growth irradiance effects on productivity, photosynthesis, nitrate accumulation and assimilation of aeroponically grown Brassica alboglabra. Journal of Plant Nutrition, 2015; 38(7), 1022-1035. doi: 10.1080/01904167.2014.963118

[46] He J, Kong S M, Choong T W, Qin L. Productivity and photosynthetic characteristics of heat-resistant and heat-sensitive recombinant inbred lines of Lactuca sativa in response to different durations of LED lighting. Acta Horticultura, 2016; 1134: 187-194. doi: 10.17660/ActaHortic.2016.1134.25

[47] He J, Qin L, Alahakoon P K D T, Chua B L J, Choong T W, Lee S K. LED-integrated vertical aeroponic farming system for vegetable poduction in Singapore. Acta Horticulturae, 2018. doi: 10.17660/ ActaHortic.2018.1227.76

[48] Yorio N C, Wheeler R M, Goins G D, Sanwo-Lewandowski M M, Mackowiak C L, Brown C S, et al. Blue light requirements for crop plants used in biore generative life support systems. Life Support Biosphere Science, 1998; 5: 119-128.

[49] Wang X Y, Xu X M, Cui J. The importance of blue light for leaf area expansion, development of photosynthetic apparatus, and chloroplast ultrastructure of Cucumis sativus grown under weak light. Photosynthetica, 2015; 53: 213-222. https://doi.org/10.1007/ s11099-015-0083-8

[50] Izzoa G , Arenab C, De Miccoa V, Capozzia F, Aronne G. Light quality shapes morpho-functional traits and pigment content of green and red leaf cultivars of Atriplex hortensis L. Scientia Horticulturae, 2019; 246 942-950. doi: 10.1016/j.scienta. 2018.11.076

[51] Miao Y, Chen Q, Qu M, Gao L, Hou L. Blue light alleviates 'red light syndrome' by regulating chloroplast ultrastructure, photosynthetic traits and nutrient accumulation in cucumber plan, Scientia Horticulturae, 2019; 257: 108680. doi: 10.1016/j.scienta.2019.108680

[52] Chen Y, Zhou B, Li J, Tang H, Tang J, Yang Z. Formation and change of chloroplast-located plant metabolites in response to light conditions. International Journal of Molecular ience 2018; 19: 1-17. doi: 10.3390/ijms19030654

[53] Savvides A, Fanourakis D, van Ieperen W. Co-ordination of hydraulic and stomatal conductances across light qualities in cucumber leaves. Journal of Experimental Botany, 2012; 63: 1135-1143. doi: $0.1093 / \mathrm{jxb} / \mathrm{err} 348$

[54] Pennisi G, Blasioli S, Cellini A, Maia L, Crepaldi A, Braschi I, Spinelli F, Nicola S, Fernandez JA, Stanghellini C, Marcelis LFM, Orsini F and Gianquinto G. Unraveling the role of red:blue LED lights on resource use efficiency and nutritional properties of indoor grown sweet basil. Frontier Plant Science, 2019; 10:305. doi: 10.3389/fpls.2019.00305

[55] Goins C D, Yorio N C, Sanwo-Lewandowski M M, Brown C S. "Life cycle experiments with Arabidopsis under red light-emitting diodes (LEDs)," Life support and biosphere science, 1998; 5: 143-149.

[56] Rabideau G S, French C S, Holt A S. The absorption and reflection spectra of leaves, chloroplast suspensions, and chloroplastfragments as measured in an ulbricht sphere. American Journal of Botany, 1946; 33: 769-777. doi: 10.1002/ j.1537-2197.1946.tb12939.x

[57] Bula R J, Morrow R C, Tibbitts T W, Barta D J, Ignatius R W, Martin T S Light emitting diodes as a radiation source for plants. HortScience, 1991; 26(2): 203-205.

[58] Sager J C, McFarlane J C. Radiation, In: Langhans R W, Tibbitts T W (Ed.), Plant Growth Chamber Handbook. Iowa State Univ. Press: North Central Region Research Publication No.340, Iowa Agriculture and Home Economics Experiment Station Special Report No. 99, Ames, IA, 1997; pp.1-29.

[59] López-Juez E, Hughes M J G. Effect of blue light and red light on the control of chloroplast acclimation of light-grown pea leaves to increased fluence rate. Photochemistry and Photobiology, 1995; 61: 106-111. doi: 10.1111/j.1751-1097. 1995.tb09250.x

[60] Goto E. Effects of light quality on growth of crop plants under artificial lighting. Environment Control in Biology, 2003; 41: 121-132. doi: 10.2525/ecb1963.41.121

[61] Furuyama S, Y, Ishigami Y, Hikosaka S, Goto E. Effects of blue/red ratio and light intensity on photomorphogenesis and photosynthesis of red leaf lettuce. Acta Horticulturae, 2014; 1037: 317-322. doi: 10.17660/ActaHortic.2014.1037.38

[62] Johkan M, Shoji K, Goto F, Hashida S, Yoshihara T. Blue light-emitting diode light irradiation of seedlings improves seedling quality and growth after transplanting in red leaf lettuce. HortScience, 2010; 45: 1809-1814. doi: 10.21273/HORTSCI.45. 12.1809

[63] Leong T Y, Anderson J M. Effect of light quality on the composition and function of thylakoid membranes in Atriplex triangularis. Biochimica et Biophysica Acta , 1984; 766: 533-541. doi:10.1016/0005-2728(84)90111-7

[64] Senger H, Bauer B. The influence of light quality on adaptation and function of the photosynthetic apparatus. Journal of Photochemistry and Photobiology, 1987; 45: 939-946. doi: 10.1111/ j.1751-1097.1987.tb07905.x

[65] Evans J R. Acclimation by the thylakoid membranes to growth irradiance and the partitioning of nitrogen between soluble and thylakoid proteins. Australian Journal of Plant Physiology, 1988; 15: 93-106.

[66] Demmig-Adams B, Adams W W III. Xanthophyll cycle and light stress in nature: uniform response to excess direct sunlight among higher plant species. Planta, 1996; 198: 460-470. doi: 10.1007/BF00620064.

[67] Tallman G, Zhu J X, Mawson BT, Amodeo G, Nouhi Z, Levy K, Zeiger E. Induction of CAM in Mesembryanthemum crystallinum abolishes the stomatal response to blue light and light-dependent zeaxanthin formation in guard cell chloroplasts. Plant Cell Physiology, 1997; 38: 236-242. http://pcp.oxfordjournals.org/content/38/3/236.full.pdf+html.

[68] Dreuw A, Fleming G R, Head-Gordon M. Role of electron-transfer quenching of chlorophyll fluorescence by carotenoids in 
non-photochemical quenching of green plants. Biochemical Society Transactions, 2005; 33: 858-862. doi: 10.1042/BST0330858

[69] Hemming S. Use of natural and artificial light in horticulture Interaction of plant and technology. Acta Horticultura, 2001; 907: 25-36. doi: 10.17660/ActaHortic.2011.907.1

[70] Joliot P, Johnson G. N. Regulation of cyclic and linear electron flow in higher plants. Proceedings of the National Academy of Sciences, 2011; 108(32): 13317-13322. doi: 10.1073/pnas.1110189108

[71] Heber U. Irrungen, Wirrungen? The Mehler reaction in relation to cyclic electron transport in $\mathrm{C}_{3}$ plants. Photosynthesis Research, 2002; 73: 223-231. doi:10.1023/A:1020459416987

[72] Heber U, Gerst U, Krieger A, Neimanis S, Kobayashi Y. Coupled cyclic electron transport in intact chloroplasts and leaves of $\mathrm{C}_{3}$ plants: Does it exist? If so, what is its function? Photosynthesis Research, 1995; 46: 269-275. doi: 10.1007/ BF00020440

[73] Miyake C. Alternative electron flows (water-water cycle and cyclic electron flow around PSI) in photosynthesis: molecular mechanisms and physiological functions. Plant Cell Physiology, 2010; 51: 1951-1963. doi: $10.1093 / \mathrm{pcp} / \mathrm{pcq} 173$

[74] Sun Y, Genga Q, Dua Y, Yang X, Zhai H. Induction of cyclic electron flow around photosystem I during heat stress in grape leaves. Plant Science, 2017; 256: 65-71. doi: 10.1016/j.plantsci.2016.12.004

[75] Huang W, Yang Y-J, Zhang S-B, Liu T. Cyclic Electron Flow around Photosystem I Promotes ATP Synthesis Possibly Helping the Rapid Repair of Photodamaged Photosystem II at Low Light. Frontier Plant Science, 2018; 9: 239. doi: 10.3389/fpls.2018.00239

[76] Shikanai T. Cyclic electron transport around photosystem I: genetic approaches. Annual. Review Plant Biology, 2007; 58: 199-217. doi: 10.1146/annurev. arplant.58.091406.110525

[77] Takahashi S, Badger M R. Photoprotection in plants: a new light on photosystem II damage. Trends Plant Science, 2011; 16: 53-60. doi: 10.1016/j.tplants.2010.10.001

[78] Long S P, Zhu X-G, Naidu S L, Ort D R. Can improvement in photosynthesis increase crop yields? Plant Cell and Environment, 2006; 29: 315-330. doi: 10.1111/j.1365-3040.2005.01493.x

[79] Raines C A. Increasing photosynthetic carbon assimilation in $C_{3}$ plants to improve crop yield: current and future strategies. Plant Physiology, 2011; 155: 36-42. doi: 10.1104/pp.110.168559

[80] Gifford R M, Thorne J H, Hitz W D, Giaquinta R T. Crop productivity and photoassimilate partitioning. Science, 1984; 24: 801-808.

[81] Koester R P, Skoneczka J A, Cary T R, Diers B W, Ainsworth E A. Historical gains in soybean (Glycine max Merr.) seed yield are driven by linear increases in light interception, energy conversion, and partitioning efficiencies. Journal of Experimental Botany, 2014; 65: 3311-3321. doi $10.1093 / \mathrm{jxb} / \mathrm{eru} 187$

[82] Weraduwage S M, Chen J, Anozie F C, Morales A, Weise S E, Sharkey T D. The relationship between leaf area growth and biomass accumulation in Arabidopsis thaliana. Frontier Plant Science, 2015; 6: 167. doi: 10.3389/fpls. 2015.00167

[83] Křístková E, Doležalová I, Lebeda A, Vinter V, Novotná A. Description of morphological characters of lettuce (Lactuca sativa L.) genetic resources. Horticultural Science (Prague), 2008; 35(3): 113-129.

[84] Evans, J R, Loreto F. Acquisition and diffusion of $\mathrm{CO}_{2}$ in higher plant leaves. In: Leegood R C, Sharkey T D, von Caemmerer S (Ed.), Photosynthesis: Physiology and Metabolism, Dordrecht: Kluwer Academic Publishers, 2000; pp.321-351. doi: 10.1007/0-306-48137-5 14

[85] Niinemets U. Components of leaf dry mass per area - thickness and density - alter leaf photosynthetic capacity in reverse directions in woody plants. New Phytologist, 1999; 144: 35-47. doi: 10.1046/ j.1469-8137.1999.00466.x.

[86] Roni M Z K, Islam I D Md S, Shimasaki K. Response of eustoma leaf phenotype and photosynthetic performance to led light quality. Horticulturae 2017; 3: 50; doi: 10.3390/horticulturae3040050

[87] Mathan J, Bhattacharya J, Ranjan A. Enhancing crop yield by optimizing plant developmental features. Development; 2016: 143: 3283-3294. doi 10.1242/dev.134072

[88] Horton P. Prospects for crop improvement through the genetic manipulation of photosynthesis: morphological and biochemical aspects of light capture. Journal of Experimental Botany, 2000; 51: 475-485. doi: 10.1093/jexbot/51.suppl_1.475

[89] Peng J, Richards D E, Hartley N M, Murphy G P, Devos K M, Flintham J E et al. 'Green revolution' genes encode mutant gibberellin response modulators. Nature, 2000; 400: 256-261. doi: 10.1038/22307

[90] Zhang T, Shi Y, Wang Y, Liu Y, Zhao W, Piao F, Sun Z. The effect of different spectral LED lights on the phenotypic and physiological characteristics of lettuce (Lactuca sativa) at picking stage. Journal Biochemistry Biotechnology, 2017; 1: 14-19. doi: 10.35841/ biochemistry-biotechnology.1.1.14-19

[91] Rahaman M M, Chen D, Gillani Z, Klukas C, Chen M. Advanced phenotyping and phenotype data analysis for the study of plant growth and development. Front. Plant Sci., 2015; 6: 619. doi: 10.3389/ fpls.2015.00619

[92] Kozai K. Smart Plant Factory: The next generation indoor vertical farms. Springer, 2018. 